\title{
Leadership styles and employees' job-related attitudes: An empirical study on the mediating effects of reciprocity and trust
}

\section{(C) Higher Education Press and Springer-Verlag 2007}

\begin{abstract}
Reciprocity and trust are the basic principles of human social exchanges. Using a sample of 972 managers in China, we examined the relationship between transformational and transactional leadership styles and job-related attitudes of employees, as well as the mediating effects of both reciprocity and trust on the above relationship based on social exchange theory. The main findings of structural equation modeling analyses were shown as follows. Firstly, transformational leadership not only affects organizational trust
\end{abstract}

Translated from Zhongda Guanli Yanjiu 中大管理研究 (China Management Studies), 2007, (1): $13-45$

JIA Liangding

School of Management, Nanjing University, Nanjing 210093, China

E-mail: jldyxlzs@jlonline.com

SONG Jiwen $(\triangle)$

School of Business, Renmin University of China, Beijing 100872, China

E-mail: songjiwen@gmail.com

\section{Chaoping}

Institute of Organizations and Human Resources, School of Public Administration, Renmin University of China, Beijing 100872, China

E-mail: lichaoping@mparuc.edu.cn

CUI Rongjun

School of Management, Nanjing University, Nanjing 210093, China

E-mail: cuirongjun.zju@163.com

CHEN Yongxia

Jinling School, Nanjing University, Nanjing 210093, China

E-mail: njucyx@sohu.com 
and commitment directly, but also motivates organizational trust of employees through the mediation of generalized and balanced reciprocity indirectly, and thus enhances organizational commitment and stay intention of employees. Secondly, transactional leadership indirectly affects organizational trust and commitment of employees through the mediation of reciprocity. Thirdly, generalized reciprocity has direct effects on organizational commitment of employees, whereas balanced reciprocity exerts its influences through affecting organizational trust of employees. Managerial suggestions are provided.

Keywords leadership styles, reciprocity, organizational trust, organizational commitment, quit intention

摘要 互惠和信任是社会交换的普适准则。基于社会交换理论, 以中国各企 业972位管理人员为样本, 研究领导风格与员工工作态度之间的关系, 以及组织与 员工间的互惠和员工的组织信任在其中的中介作用。最后得出 3 点结论：(1) 变革 型领导不仅直接对员工的组织信任和组织承诺产生作用, 而且通过组织对员工的 广义和平衡互惠使员工产生对组织的信任, 从而提高员工的组织承诺和降低员工 的离职意愿; (2) 事务型领导仅仅通过互惠对员工的组织信任和组织承诺产生作 用; (3) 广义互惠直接影响员工的组织承诺, 平衡互惠通过组织信任影响员工的组 织承诺。

关键词 领导风格, 互惠, 组织信任, 组织承诺, 离职意愿

\section{Introduction}

Over the past two decades, the focus on leadership styles has shifted from the traditional or transactional models to a new genre of leadership theory, with charisma as its core concept (Pillai et al., 1999). The tendency occurred because of the promise of extraordinary individual and organizational outcomes due to inherent "charisma" (Meindl, 1990; Shamir et al., 1993). Substantial empirical studies demonstrate that there is a positive correlation among different leaderships, especially transformational leadership and employees' attitudes and performance (Burns, 1978; Bass, 1985; Dvir et al., 2002; Shin and Zhou, 2003; Avolio et al., 2004; Wanget al., 2005). After a brief review of the research and development in leadership of the past two decades, particularly in transformational leadership, Bass (1999a; 1999b) pointed out that more attention should be paid to the influencing process of transformational leadership on employees' attitudes in our future research.

Employees' job-related attitudes have three components: cognition, affection and behavior. Most studies mainly focus on the affective components (such as 
organizational commitment, job satisfaction, quit intention) and behavioral ones (such as organizational citizenship behavior, absenteeism) (Robbins and Coulter, 2004). In this paper, organizational commitment and quit intention are chosen as variables of employees' job-related attitudes. We sampled 972 managers from firms in various ownership styles, who are mainly from the industrial sectors of manufacturing, energy, construction and communication. About $80 \%$ of them have a bachelor or a master degree, with the average age of 33 and more than 10 years work experience. Since the 1990s, the education of business administration has witnessed great headway in China. Most well-educated MBAs have assumed the management positions of enterprises. Our samples are typical representatives from firm managers in the mainstay of enterprises. Organizational commitments of managers, for example, identification with, involvement in and loyalty to the organization, are all most important sources of sustainable competitive advantage of firms.

One of the theoretic perspectives to explore the influencing process of leadership on job-related attitudes of employees is social exchange theory (Bass, 1985; Wayne et al., 1997). Blau (1988) suggested that the basis of any exchange relationship can be described in terms of either social or economic principles. When one gives others help or does somebody a favor, he would expect to be rewarded in the future. Future returns will be built on the belief that others would return fairly in the long run. Social exchanges in nature are based on a trust that goodwill will be reciprocated at some point in the future (Settoon et al., 1996). The expectation of long-term fairness in social exchange contrasts with the expectation of short-term fairness, which is typically characterized by economic exchanges (Konovsky and Pugh, 1994). Therefore, reciprocity, trust and fairness are the important factors that affect the exchange relationship between leaders and employees.

Pillai et al. (1999) studied the mediating effects of fairness and trust on the relationship between leading styles and job-related attitudes. The research suggested that the way how mediating effects of transformational leadership exert on organizational citizenship behaviors of employees is through procedural justice and trust. Few studies explained the influencing process of organizational trust and employees' attitudes from the perspective of reciprocity. In this paper, we studied the mediating roles of reciprocity and trust in the relationship between leadership styles and job-related attitudes of employees. There are two reasons why we chose reciprocity as an important mediating variable. First, Gouldner (1960) stated that "contrary to some cultural relativists, it can be hypothesized that a norm of reciprocity is universal". In other words, this norm governs exchange relationships in all spheres of life and in all cultures (Tetrick, et al., 2004). The norm of reciprocity behind the varied sorts of individual-individual or organization relationships refers to exchange partners' motives and the immediacy 
and equivalency of exchanged resources (Wu et al., 2006). Second, the distinctions between economic and social exchanges did not demonstrate why social exchange leads to trust (Butler, 1991; McAllister, 1995), and the dimensions of actual exchange behavior that distinguish social exchange from economic exchange have not been specified in a way that facilitates empirical verification (Sparrowe and Liden, 1997). Therefore, this paper tries to explore the exchange relationship between leaders and subordinates based on the norm of reciprocity. Reciprocity, aroused from leadership style, can lead to the organizational trust of employees, and the trust in turn may give rise to high organizational commitment and low quit intention of employees.

The theoretical model is shown in Fig. 1. Based on social exchange theory, this study explores the mediating effects of reciprocity and trust on the association between leadership styles and job-related attitudes of employees. As far as we are concerned, there have been very few studies focusing on the topic at home and abroad. Therefore, from the perspective of social exchange, we aim to unpack the black-box of influencing process of leadership on employees' attitudes by testing the mediating effects of reciprocity and trust on the relationship between leadership and job-related attitudes of employees.

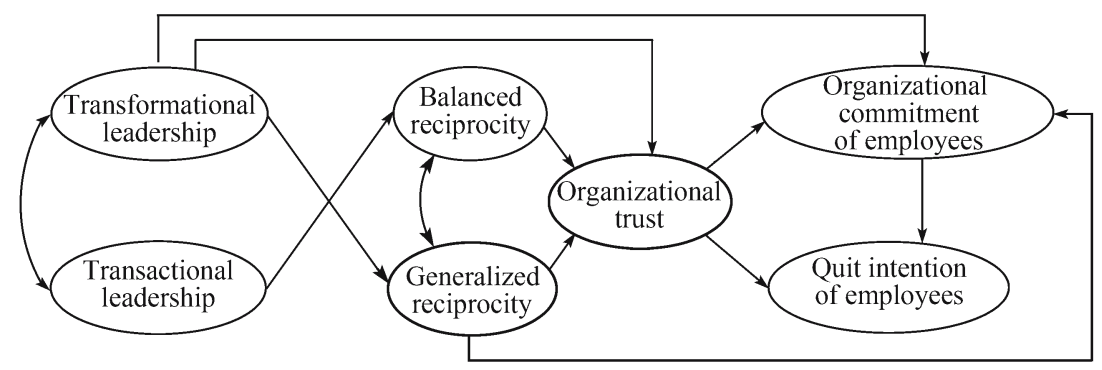

Fig. 1 Model of the mediating effects of reciprocity and organizational trust on the relationship between leadership styles and job-related attitudes of employees $\left(\mathrm{M}_{\mathrm{T}}\right)$

\section{Theories, conceptual model and hypotheses}

\subsection{Relationship between leadership styles and reciprocity}

According to Bass (1985), transactional leaders clarify their subordinates' responsibilities, specify the tasks that must be fulfilled, and provide benefits to the subordinates correspondingly. Nevertheless, transformational leaders motivate their subordinates to perform beyond expectations by stimulating subordinates to transcend self-interest for the sake of their organization (Bass, 1985; Pillai 
et al., 1999). Therefore, transactional leadership style is based on material or economic exchange while the latter on social exchange (Bass, 1985; Pillai et al., 1999). The four dimensions of transformational leadership conceptualized by Bass and Avolio (1993) consist of charisma or idealized influence, inspirational motivation, intellectual stimulation and individualized consideration. Largely based on the work of House (1997) and his colleagues (Shamir et al., 1993). Waldman et al. ( 2001) presented that transformational leadership style actually includes the leadership behaviors and favorable influences on followers. Key leadership behaviors include articulating a vision, conveying a mission, showing determination and communicating expectations for high performance. Favorable influences on followers include generating confidence in the leader, making followers feel good, and generating strong admiration and respect for the leader.

The relationship between a leader and his/her subordinates can be regarded as an exchange relationship. The principle of reciprocity is universal for human activities despite cultural differences (Gouldner, 1960). The same principle is also applied to China, as a famous Chinese idiom goes "if one receives a plum, one must return a peach". Reciprocity is a part of traditional Chinese philosophy and values. Drawing on the ethnographic records on a broad range of cultures, Sahlins (1972) introduced a typology comprising three dimensions of reciprocity, for example, equivalence of returns, immediacy of returns and interest. Sparrowe and Liden (1997) constructed three types of reciprocity on the basis of different configurations of these three dimensions of Sahlins (1972), including generalized, balanced and negative reciprocities. Generalized reciprocity represents an indefinite reimbursement period, undefined equivalency of return, and low selfinterest. Givers included in this type of exchange do not expect recipients to pay back in a predetermined period of time with something of equal value. If the employee-organization relationship embraces this sort of exchange, then the organization may make an open-ended, unspecified, broad investment to its employees, not expecting its employees' immediate and equivalent reimbursement. Balanced reciprocity reflects a simultaneous exchange of equivalent resources. If the employee-organization relationship embraces this sort of exchange, it indicates that the organization invests in employees and expects its employees to reimburse with something of equal value within a short time span. Negative reciprocity is characterized by timely, equivalent returns, and high self-interest. Givers included in this form of exchange are taking-oriented and seek to maximize their self-interests even at the expense of the recipients. In this paper, we only take into consideration the first two types of reciprocity: generalized and balanced. Bryman (1992) argued that a charismatic leader enhanced the psychological empowerment of its followers through clear articulation and communication of vision and mission with its followers. Subsequently, the communication between the leader and followers increases, and the followers' perception of justice is 
enhanced (Tyler, 1986; Niehoff and Moorman, 1996; Pillai et al., 1999). Therefore, through articulating and communicating vision and mission with employees, transformational leaders may generate generalized reciprocity between the organization and employees, and make employees convinced that their interests are concerned. Meanwhile, when an organization treats its employees well and respects their work, employees will devote more expected in-role and extra-role behaviors (Settoon et al., 1996; Wayne et al., 1997). Motivated by transformational leaders' shared vision, role modeling in the work and respect for employees, employees will concern mutual interests with respect to their employing organization, and make ex ante investment to the organization due to a belief in future returns. Such extant mutual investments will reinforce generalized reciprocity between organization and employees.

On the other hand, transactional leadership is more based on the economic exchange process in which the leader provides rewards in return for the followers' effort and performance (Pillai et al., 1999). In this type of exchange with high emphasis on the association between rewards and performance (Pillai et al., 1999), employees may consider the relationship between the organization and them as a pure effort-reward relationship. Effective transactional leaders are capable of meeting and responding to the reactions and changing expectations of their followers (Kellerman, 1984). This is in nature the principle of balanced reciprocity: both employer and employees concern the equivalent and immediate reimbursements of self-interest. Therefore, we get the following hypotheses.

H1: transformational leadership is positively related to generalized reciprocity between the organization and its employees.

H2: transactional leadership is positively related to balanced reciprocity between the organization and its employees.

\subsection{Mediating effects of reciprocity on the association between leadership styles and organizational trust}

Trust is one's expectations, assumptions, or beliefs about the likelihood that another's future actions will be beneficial, favorable, or at least not detrimental to one's interests (Robinson, 1996). As a positive attitude to others or social entities, trust plays a central role in all sorts of relationships or contracts. There are two qualitatively different theoretical perspectives of trust, explaining the processes of how trust forms and how trust affects workplace outcomes (Dirks and Ferrin, 2002). One is the relationship-based perspective, in which trust is based on social exchange theory (Whitener et al., 1998; Pillai et al., 1999). The other is character-based perspective, in which trust is based on followers' perception of a leader's characters, such as integrity, dependability, fairness, and competence (Mayer et al., 1995). 
Transformational leadership is based on the compliance of employees, which involves shifts in the beliefs, the needs, and the values of employees (Kuhnert and Lewis, 1987). Both Bass (1985) and Burns (1978) indicated that transformational leaders influence employees' deep-level personal value systems that include values such as fairness and integrity. Transformational leaders act as role models for subordinates, transcend their interests, and unite them to achieve organizational goal (Bass, 1985). By developing a shared vision, transformational leaders may establish mutual trust with employees (Pillai et al., 1999). Based on the above analyses, we develop a hypothesis as below.

H3: transformational leadership is positively related to the organizational trust of employees.

The typical characteristics of generalized reciprocity are open-ended, unspecified responsibilities, low self-interest and high concern for the other's interests. An organization emphasizes the career development of employees, invests in its employees without a requirement for immediate return. Employees are thus willing to contribute, because they believe that they will get a fair return in the future. According to Blau (1988), social exchanges entail unspecified obligations. When one does another a favor, there is an expectation of some future return, though exactly when it will occur and in what form are often unclear (Wayne et, al., 1997). McCabe et al. (2003) pointed out that only when one party takes risks in the exchange with the other view it as trust and return actively. When one party in the exchange takes no risk or just few costs, the other will not consider the activity as trust, nor intend to establish a balanced reciprocity. If the relationship between an organization and its employees is a kind of generalized reciprocity, the organization will invest in its employees (such as career development) in advance, and thus take more risks and entail greater expenses. Employees in such organizations will tend to develop a sense of trust and recognition to the organization. On the other hand, when the relationship between an organization and its employees is a kind of balanced reciprocity, the organization requires its employees to equivalently pay back the investment made by the organization immediately. To illustrate, in a balanced reciprocity relationship, an organization prefers clear-defined job description as well as quick and lucrative training projects for its employees. Such choices would entail fewer risks to the organization itself. We argue that the balanced reciprocity of the organization with its employees will result in lower level of organizational trust of employees than that of generalized reciprocity. Given these assumptions, we develop the following hypotheses.

H4: generalized reciprocity is positively related to organizational trust of employees, and its effect is stronger than that of balanced reciprocity.

H5: balanced reciprocity is positively related to organizational trust of employees. 
The relationship between leaders and employees can be explained with social exchange theory (Bass, 1985; Wayne, et al., 1997). According to Blau (1988), there are two necessary conditions that enable an exchange behavior to be a social exchange: first, the ultimate goal of the exchange behavior can only be achieved through the interactions with others; second, the exchange behavior must take the means conducive to the goals. There was a clear connection between power and social exchange (Blau, 1988), and power was viewed as emergent property of social exchange. Power will be seen as legitimate if the costs for the subjects are less than the benefits they get from the ruler. If not, they will feel exploited. Although legitimate power is a basis of organization, employees will show more willingness of compliance if the leaders can master both authorities inherent in a position and influences inherent in an individual. In an organization, the relationship between leaders and employees actually is a social exchange relationship based on the legitimate power and individual influences. If a leader neglects the fairness in exchange relationship with employees, or fails to show justice in management, the authority will be ineffective (Tyler and Caine, 1981). Therefore, we view reciprocity as a mediating variable between leadership style and organizational trust and commitment of employees. The transformational leadership style may be more likely to arouse organizational trust of the employees through exchange of generalized reciprocity, while the transactional leadership style does so through balanced reciprocity. The higher the mutual responsibilities, the greater intensity of social exchange and the more benefits employees gain from the exchanges due to the more possibilities for both exchange parties to continuously maintain this reciprocal exchange (Shore and Shore, 1995). The transformational leadership brings the employees' trust through charisma and inspirational motivation, while the transactional leadership tends to create an economic exchange environment, which emphasizes the clear association between performance and rewards (Pillai et al., 1999). Although economic exchange does not produce the trust of employees directly, it may do so indirectly because it can enhance the employees' perception of fairness and immediacy in the exchange. Thus, the following hypotheses seem reasonable.

H6: generalized reciprocity has a partial mediating effect on the relationship between transformational leadership and the organizational trust of employees.

H7: balanced reciprocity has a full mediating effect on the relationship between transactional leadership and the organizational trust of employees.

2.3 Direct relationship between transformational leadership and organizational commitment

Following prevailing practices, this paper interprets the organizational commitment of employees as an affective commitment, which refers to 
employees' emotional attachment to, identification with, and involvement in the organization (Allen and Meyer, 1990). According to this definition, organizational commitment indicates a strong belief in the organizational goals and values (recognition), a willingness to devote considerable efforts on the behalf of the organization (involvement) and a strong intent or desire to remain with the organization (loyalty) (Meyer and Allen, 1984; Allen and Meyer, 1990; Yousef, 2000). Voluminous empirical studies conducted in different contexts of organizations and cultures show that transformational leadership style is positively related to organizational commitment (Bycio et al., 1995; Chen, 2002; Avolio, et al., 2004). Transformational leadership style induces employees' trust in and respect for their leaders, thus employees will exert additional efforts beyond expectations (Yukl, 1989). Subordinates will internalize the values of transformational leaders, and pursue the organizational mission beyond their own interests (Howell and Avolio, 1993). Transformational leaders can arouse needs for achievement, affiliation and power, which will enhance self-assessment of the employees and ultimately reinforce the employees' commitment to the mission (Bass, 1999a). Some empirical studies by domestic scholars also demonstrate that transformational leadership has a positive impact on employees' extra efforts and organizational commitment (Li and Shi, 2003; Meng, 2004; Chen et al., 2006). Drawing on the above rationale, we propose the following hypothesis.

H8: transformational leadership is positively related to employees' organizational commitment.

\subsection{Direct relationship between generalized reciprocity and organizational} commitment

The meta-analysis by Rhoades and Eisenberger (2002) showed that affective commitment and employee's perceived organizational support are highly correlated $(r=0.73)$. Employees' involvement in and identification with an organization may highly relate to generalized reciprocity, because generalized reciprocity reflects the organizational investment in the employees beyond its self-interest without requesting any immediate and equivalent imbursement from employees. However, in a balanced reciprocity relationship, an organization focuses on immediate and equivalent return. Even if an equivalent exchange may directly affect employees' organizational commitment, such influences would not be prominent enough. Wu et al. (2006) demonstrated that there is no significant relationship between balanced reciprocity and organization commitment. We therefore propose the following hypothesis.

H9: generalized reciprocity is positively related to organizational commitment of employees. 
2.5 Relationships among organizational trust, organizational commitment and quit intention of employees

Employees with a high level of organizational trust will give more support to their organization, such as organization commitment. If an employee trusts the organization and his/her leaders, he/she will comply with the decisions made by the leaders, stick to the shared vision and values, contribute high level efforts to the organization and prefer staying in the organization. On the contrary, if the employee distrusts the organization, he/she will cast doubt on the decisions, reluctant to take any risk due to lack of trustworthiness, and this will result in low organizational commitment. The positive association between organizational trust and organizational commitment has been confirmed in empirical studies (Brockner et al., 1997; Dirks and Ferrin, 2002). Siegel et al. (1995) argued that if an organization has established employees' organizational trust, it can maintain organizational commitment even during an economic depression period. Thus, we propose the following hypothesis.

\section{H10: employees' organizational trust is positively related to organizational commitment.}

Employees' turnover is an important management issue because turnover not only increases costs of re-recruitment and training, but also impairs the stability of an organization. In this study, we used the construct of quit intention to describe employee's turnover intention due to its high predictive power of real turnover (Fishbein, 1967; Newman, 1974; Mobley et al., 1978; Michaels and Spector, 1982). Roberts et al. (1999) demonstrated that employees' organizational trust can reinforce the relationship between employees and their organization. McNeilly and Lawson (1999) found that salesmen who trust their leaders can accept the organization changes more easily. Trust is also an important factor in group-values model (Tyler, 1989), in which the trust between an organization and its employees would lead to greater attention to the interests of their counterparts. Trust could entail strong bondage between employees and their organization, resulting in employees' loyalty.

H11: the more organizational trust employees have, the lower quit intention they possess

Mobley et al. (1978) pointed out that organizational commitment should be considered in the future studies as a predictive variable to turnover. Organizational commitment is viewed as a more pervasive component of job-related attitude of employees and a more inherent intent to sustain employees' behaviors even when the expected benefits or returns are not actualized (DeCoutis and Summers, 1987). Substantial studies have shown a negative correlation between organizational commitment and quit intention (O'Reilly and Caldwell, 1980; Ferris and Aranya, 1983; Stumpf and Hartman, 1984; Cotton and Tuttle, 1986). 
Many studies have confirmed that organizational commitment has a stronger and more direct effect on quit intention than job-related satisfaction does (Williams and Hazer, 1986; Shore and Martin, 1989; Mueller and Price, 1990; Lum et al., 1998). The employees with a high level of organizational commitment are more willing to stay in the organization and strive to fulfill organizational goals (Stumpf and Hartman, 1984). Therefore, we develop our final hypothesis as follows.

H12: organizational commitment of employees has a negative effect on quit intention of the employees.

\section{Research methods and procedures}

\subsection{Initial research}

The measurement scales of mentioned constructs are mainly selected from Western scholars' academic publications. The scales of transformational and transactional leadership are based on the study of Waldman et al. (2001). The items used in Waldman et al. (2001) come from Bass (1985) and MLQ (multifactor leadership questionnaire) by Bass and Avolio (1990). So we chose from MLQ a scale of four items and three items, and added them into the transformational and transactional leadership scales of Waldman et al. respectively (2001).

The scale of reciprocity comes from the study of $\mathrm{Wu}$ et al. (2006). The organizational trust scale has seven items in the work of Robinson (1996). The scale of organizational commitment is mainly based on the work of Meyer and Allen (1997), Chen and Francesco (2003). We chose eight items from their scales (Meyer and Allen, 1997; Chen and Francesco, 2003) to measure employees' affective commitment. The scale of employees' quit intention is from the studies conducted by Bluedorn (1982) and Wang et al. (2002). In this study, a six-point Likert scale was employed, in which 1 represents "completely disagree" and 6 "completely agree".

\subsection{Research sample}

Faculty members from full-time business school in eleven Chinese universities were invited to distribute and collect the questionnaires. All questionnaires were distributed and collected in classes, most of which were the MBA classes, and very few were classes of continuous education of business administration. Although the exact return rate was not recorded, we can ensure that most of the distributed questionnaires were returned due to the reason that the distribution and collection were held in class. In total, 1,128 valid questionnaires were returned in the above eleven universities and the average number of respondents 
in each university was 103, with the maximum number of 197 and the minimum number of 28 .

Our study examined middle managers for they are proximal to CEOs and are more likely influenced by CEO leadership styles. Therefore, the respondents are better to be middle managers in the firms with a considerable firm size and firm history. Our final data were screened by the following criteria. First, the respondents without any subordinates were eliminated. Second, the respondents working in the firms with less than 30 total employees were eliminated. Third, the respondents in the firms founded within 12 months were eliminated. Therefore, the case number of our final sample was 972 .

In the final sample, the average firm age is 17 years, the average number of total employees is 2,004, and these firms come dispersedly from many industries and most of them cluster in four industries, including manufacturing, communication, construction, and energy. $64.5 \%$ of the respondents are male, $79.3 \%$ have at least undergraduate education, and most of the respondents are engaged in functions such as marketing, general administration, human resources management, finance and accounting as well as information management. In average, the respondents are at an age of 33 years old, having 10 years working experience, having 15 subordinates, and having worked together with the current CEO for 3.5 years.

\subsection{Analyses}

The sample with 972 cases was randomly divided into two parts. While the first part of 486 middle managers was used for exploratory factor analysis and the other was for confirmatory factor analysis. The overall sample with 972 middle managers was adopted for the hypothesized model testing.

\subsubsection{Exploratory factor analysis: The first part with 486 cases}

\subsubsection{Leadership: transformational and transactional leadership}

The measure of leadership styles have 14 items. However, in transactional leadership measure, four items (three items measuring "management by exception" and one measuring "contingency pay") have high cross-loading with transformational leadership in exploratory factor analysis. Therefore, we use the remained ten items in the further analyses. The main contents of the scale are charisma and inspirational motivation of transformational leadership, and contingent compensation of transactional leadership. The correlation coefficient matrix of the ten items shows that the MSA (measures of sampling adequacy) of each item is greater than 0.7 and the overall MSA is 0.86 . The chi-square of 
Bartlett test is $1,447.46(d f=45, p<0.01)$ and the correlations among ten items are all significant at the level of 0.01 , which satisfy the preconditions of factor analysis. Altogether, $55.02 \%$ of the total variance is explained by a two-factor model which is shown in Table 1.

Table 1 Exploratory factor analysis of leadership styles

\begin{tabular}{|c|c|c|}
\hline & Factor 1 & Factor 2 \\
\hline \multicolumn{3}{|l|}{ Factor 1: transformational leadership } \\
\hline 1. Shows determination when accomplishing goals. & 0.675 & \\
\hline 2. Makes people feel good to be around him/her. & 0.686 & \\
\hline 3. Goes beyond self-interest for the sake of the group. & 0.590 & \\
\hline 4. Displays a sense of power and confidence. & 0.780 & \\
\hline $\begin{array}{l}\text { 5. Convey high performance expectations to } \\
\text { the subordinates. }\end{array}$ & 0.618 & \\
\hline $\begin{array}{l}\text { 6. Talks enthusiastically about what needs to } \\
\text { be accomplished. }\end{array}$ & 0.707 & \\
\hline 7. Articulates a compelling vision of the future. & 0.661 & \\
\hline 8. Transmits a sense of mission. & 0.696 & \\
\hline \multicolumn{3}{|l|}{ Factor 2: transactional leadership } \\
\hline $\begin{array}{l}\text { 1. Points out what people will receive if they do } \\
\text { what needs to be done. }\end{array}$ & & 0.900 \\
\hline $\begin{array}{l}\text { 2. Reinforces the link between achieving goals } \\
\text { and obtaining rewards. }\end{array}$ & & 0.851 \\
\hline
\end{tabular}

Note: We use principal component analysis and Varimax rotation with Kaiser Normalization. The factor loadings not shown are all below 0.4.

\subsubsection{Reciprocity: generalized and balanced reciprocities}

We adopt Wu et al. (2006)'s nine items measure of generalized and balanced reciprocity. The nine items' correlation matrix reveals that the MSA of each item is greater than 0.78 and the overall MSA is 0.86 . The chi-square of Bartlett test is $1,508.48(d f=36, p<0.01)$ and the nine items are all significantly correlated at the level of $0.01 .60 .11 \%$ of the total variance is explained by a two-factor model as shown in Table 2.

\subsubsection{Organizational trust}

We measure organizational trust by using Robinson (1996)'s seven items. The correlation matrix of the seven items shows that the MSA of each item is greater than 0.90 and the overall MSA is 0.92 . The chi-square of Bartlett test is 2,120.73 $(d f=15, p<0.01)$ and seven items are all significantly correlated at the level of 0.01 . One factor model explains $67.45 \%$ of the total variance, as shown in Table 3. 
Table 2 Exploratory factor analysis of reciprocity

Factor 1

Factor 2

Factor 1: generalized reciprocity

1. My organization would help me develop myself, even if I cannot make more contributions at present.

2. My organization seems willing to invest in my professional development, even when it does not directly impact my current job performance.

3. My organization would do something for me without any strings attached.

4. My organization takes care of me in ways that exceed my contributions to it.

Factor 2: balanced reciprocity

1. My organization takes care of the organization's interests as much as my interests.

2. It seems important to my company that my efforts are equivalent to what I receive from it.

3. If I do my best and perform well, my organization will give me the opportunity for promotion.

4. If my job performance exceeds my organization's need, my organization will give me an extra reward.

5. As long as I show my concern for the welfare of the organization, the organization will be concerned for my welfare in return.

Note: We use principal component analysis and Varimax rotation with Kaiser Normalization. The factor loadings not shown are all below 0.4 .

Table 3 Exploratory factor analysis of organizational trust

Organizational trust Factor 1

1. I believe my employer has high integrity.

2. I can expect my employer to treat me in a consistent and predictable fashion. $\quad 0.858$

3. My employer is always honest and truthful. $\quad 0.830$

4. In general, I believe my employer's motives and intentions are good. $\quad 0.784$

5. I think my employer treats me fairly.

6. My employer is open and upfront to me.

7. I fully trust my employer.

0.816

Note: We use principal component analysis and Varimax rotation with Kaiser Normalization.

\subsubsection{Organizational commitment}

The correlation matrix of the eight items shows that the MSA of each item is greater than 0.85, the overall MSA is 0.92. The chi-square of Bartlett test is $2,107.63(d f=28, p<0.1)$ and the correlation among the eight items are all 
significant at the level of 0.01 . And $61.86 \%$ of the total variance is explained by one factor shown in Table 4.

Table 4 Exploratory factor analysis about organizational commitment

\begin{tabular}{lc}
\hline Organizational commitment & Factor 1 \\
\hline 1. I enjoy discussing my organization with people outside & 0.612 \\
2. I really feel that this organization's problems are my own. & 0.785 \\
3. I think I could not easily become as attached to another organization as & 0.739 \\
I am to this one. & \\
4. I feel like "part of the family" at my organization. & 0.796 \\
5. I feel "emotionally attached" to this organization. & 0.843 \\
6. I feel a strong sense of belonging to my organization. & 0.830 \\
7. I would be very happy to spend the rest of my career in this organization. & 0.821 \\
8. This organization has a great deal of personal meaning for me. & 0.839 \\
\hline
\end{tabular}

Note: We use principal component analysis and Varimax rotation with Kaiser Normalization.

\subsubsection{Quit intention}

The correlation matrix of four items shows that the MSA of each item is greater than 0.80 and the overall MSA is 0.84 . The chi-square of Bartlett test is 1,070.05 $(d f=6, p<0.01)$ and the four items are all significantly correlated at the level of 0.01 . One factor model explains $75.80 \%$ of the total variance. The result is shown in Table 5.

Table 5 Exploratory factor analyses about quit intention

\begin{tabular}{lc}
\hline Quit intention & Factor 1 \\
\hline 1. I might quit the current job and join another company in the next year. & 0.858 \\
2. I often think about quitting my job at this organization. & 0.880 \\
3. I am not planning to stay in this organization to develop my career. & 0.887 \\
4. There is no hope for me in this company. & 0.858 \\
\hline
\end{tabular}

Note: We use principal component analysis and Varimax rotation with Kaiser Normalization.

\subsubsection{Confirmatory factor analysis:The second part with 486 cases}

\subsubsection{Leadership styles}

The two-factor structure of transformational and transactional leadership nicely fits our sample data $\left(\chi^{2}=99.92, d f=33, G F I=0.96, R M S E A=0.067\right.$, $C F I=0.96 . T L I=0.94)$. The reliabilities of transformational and transactional leadership are 0.86 and 0.79 respectively. 


\subsubsection{Reciprocity}

The two-factor structure of generalized and balanced reciprocity fits well with the sample data $\left(\chi^{2}=115.54, d f=25, G F I=0.95, R M S E A=0.090, C F I=0.95\right.$. $T L I=0.93)$. The reliabilities of generalized and balanced reciprocity are 0.80 and 0.84 respectively.

\subsubsection{Organizational trust}

The one factor structure of organizational trust fits well the data $\left(\chi^{2}=69.29\right.$, $d f=14, G F I=0.96, R M S E A=0.091, C F I=0.97, T L I=0.96)$. The reliability of organizational trust is 0.90 .

\subsubsection{Organizational commitment}

One factor structure of organizational commitment fits very well with the data $\left(\chi^{2}=65.09, d f=20, G F I=0.97, R M S E A=0.070, C F I=0.97, T L I=0.96\right)$. The reliability of organizational commitment is 0.90 .

\subsubsection{Quit intention}

One factor structure of quit intention has an almost perfect fit with the data $\left(\chi^{2}=0.79, d f=2, G F I=1.00 . R M S E A=0.00, C F I=1.00, T L I=1.00\right)$. The reliability of quit intention is 0.89 .

In sum, the results of both exploratory and confirmatory factor analysis demonstrate that the measurement properties of each variable are qualified for further analyses (Hair et al., 1998; Kelloway, 1998).

\subsection{Data analysis methods}

We used the overall 972 cases to test the proposed model in LISREL. Following Wang et al. (2005) and other researchers, we employed a method of two-step analysis to examine the hypotheses. In the first step, confirmatory factor analysis was used to test the discriminant validity among the seven variables, i.e. transformational leadership, transactional leadership, generalized reciprocity, balanced reciprocity, organization trust, organizational commitment and quit intention. In the second step, we firstly compared and analyzed the theoretical model with its several nested models. Then, based on the results of the first step, we used the decision-tree approach proposed by Anderson and Gerbing (1988) to compare the theoretical model $\left(\mathrm{M}_{\mathrm{T}}\right)$ with other alternatives and seek the most reasonably interpretive model. 


\section{Results}

\subsection{Tests about common method variance and discriminatant validity}

As all variables in this study were in one questionnaire and each respondent completed the self-report questionnaire in a certain time period, there might be the problem of common method variance which is criticized by many researchers (Podsakoff and Organ, 1986; Spector, 1994; Podsakoff et al., 2003). To minimize the common method variance, in our questionnaire design stage, we adopted different instructions for different scales, and placed the adjacent variables in the proposed model in discrete sessions. Appropriate arrangements for the order of questionnaire items can reduce a respondent's consistent motive to a certain extent, and thus decrease the common method bias in self-report (Podsakoff and Organ, 1986; Podsakoff, et al., 2003). In addition, we used Harman's single-factor test to check the extent of common method bias existed in data. The items of all variables were put together in the factor analysis. Exploratory factor analysis shows a clear seven-factor structure. The first un-rotated factor explains $32.65 \%$ of the total variance, and the seven factors explain $63.87 \%$ of the total variance. The results of confirmatory factor analysis given in Table 6 show that transformational leadership, transactional leadership, generalized reciprocity, balanced reciprocity, organization trust, organization commitment and quit intention are different constructs with good discriminatant validity.

\subsection{Descriptive statistics, correlation coefficients and multi-co linearity test}

The means, standard deviations, Pearson's correlation coefficients and reliability coefficients of seven variables are presented in Table 7. The values of Cronbach's alpha represent the internal consistency of the seven variables ranging from 0.90 to 0.79 .

Three methods were used to test the multicollinearity among variables. First, according to Rockwell (1975), the correlation coefficients among variables are all less than 0.80 , and the largest one is the correlation between organizational trust and commitment, which is up to 0.792 . Second, we had quit intention as the dependent variable and entered the other six variables into the regression model step by step. The change of $\mathrm{R}$ square in each step is significant at the level of 0.01 , which means that each variable adds the significant explanation power. Third, we had quit intention as the dependent variable and all the other six variables as independent variables, the VIF (variance inflation factor) of each independent variable is less than 2, of which the largest one is 1.052 and the least is 1.987. Therefore, there is no serious problem of multi-co linearity and the data are appropriate for further analysis of structural equation modeling. 


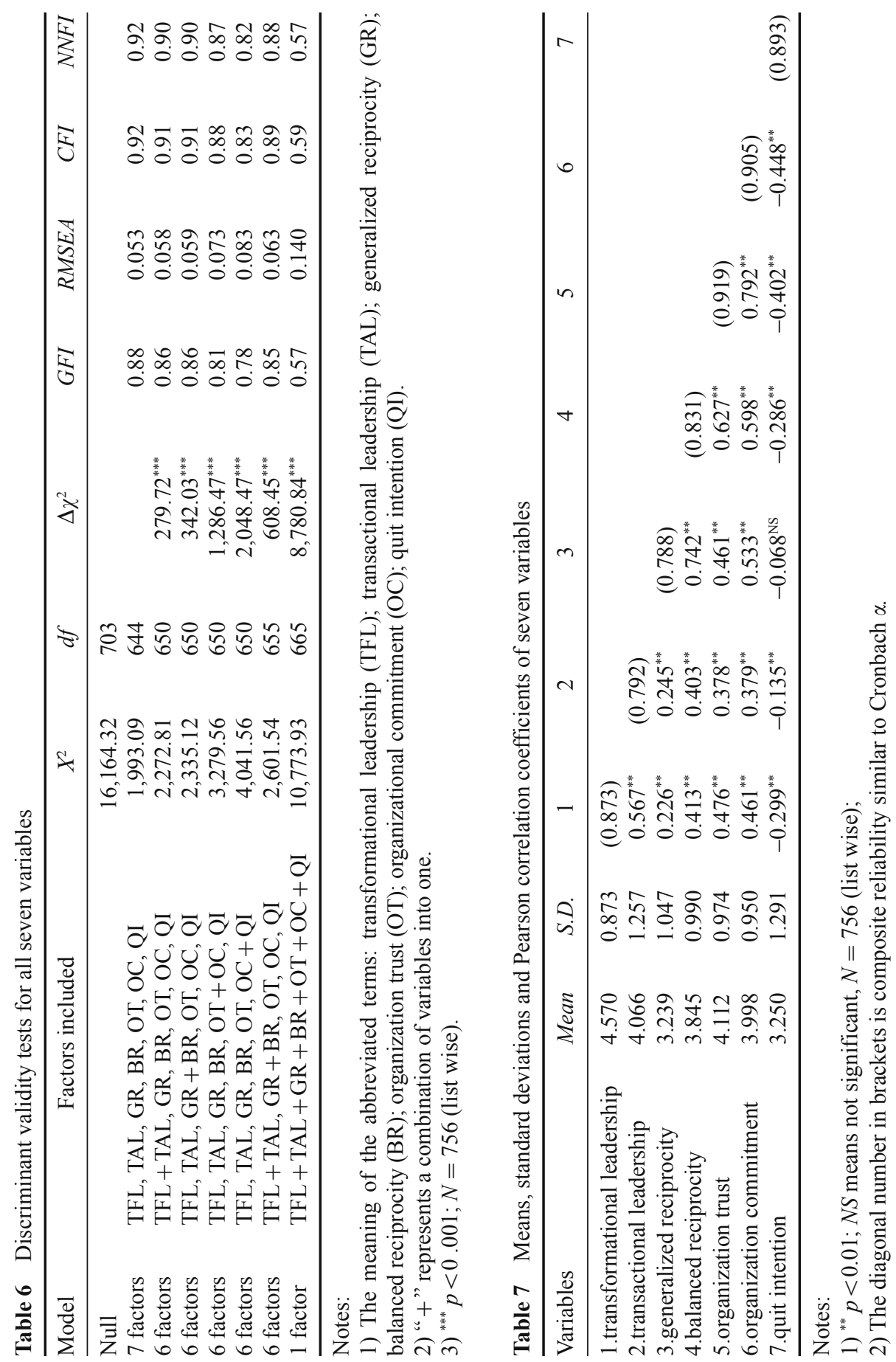




\subsection{Results of structural equation model}

Each of the seven variables - transformational leadership, transactional leadership, generalized reciprocity, balanced reciprocity, organizational trust, organizational commitment and quit intention - was measured in a single-factor way. According to the suggestions by Jöreskog and Sörbom (1993) and Kelloway (1998), for single-factor variable, the value of the error variance of each variable in structural equation is the product of this variable's variance and the difference between 1 and reliability, i.e. the variance $\times(1$-composite reliability). The loading for each factor is the product of reliability coefficient and standard deviation, i.e. composite reliability $\times$ standard deviation. Two steps were taken to compare among different nested structural models. First, we compared and analyzed the theoretical model with several nested models. Second, based on this result, we tested the theoretical model and sought the most preferable model using the decision-tree approach suggested by Anderson and Gerbing (1988). The goodness-of-fit indexes of each structural model are shown in Table 8.

4.3.1 First step analysis: the comparison between the theoretical model and several nested models (see $\mathrm{M}_{\mathrm{T}}$ to $\mathrm{M}_{4}$ in the upper part of Table 8)

\subsubsection{Theoretical model $\left(\mathrm{M}_{\mathrm{T}}\right)$}

Only GFI exceeds the recognized critical value of 0.90 , thus the goodness-of-fit indexes of $\mathrm{M}_{\mathrm{T}}$ are not satisfactory. Nine of the ten paths in $\mathrm{M}_{\mathrm{T}}$ are significant at the level of 0.01 , and the other is not significant at the level of 0.05 .

\subsubsection{Model $1\left(\mathrm{M}_{1}\right)$}

$M_{1}$ is based on $M_{T}$ by freeing the path from transactional leadership to organizational trust. Compared with $\mathrm{M}_{\mathrm{T}}$, the $\chi^{2}$ change of $\mathrm{M}_{1}$ is not significant $\left(\Delta \chi^{2}=0.16, \Delta d f=1, p=0.69\right)$, and $A G F I, N N F I, P N F I$ and GFI decrease slightly while RMSEA rises slightly. Therefore, adding the direct relationship between transactional leadership and organizational trust did not enhance the explanatory power of the model even though at the expense of parsimony.

\subsubsection{Model $2\left(\mathrm{M}_{2}\right)$}

$\mathrm{M}_{2}$ is based on $\mathrm{M}_{\mathrm{T}}$ by freeing the path from balanced reciprocity to organizational trust. Compared with $\mathrm{M}_{\mathrm{T}}$, the $\chi^{2}$ change of $\mathrm{M}_{2}$ is not significant $\left(\Delta \chi^{2}=0.31\right.$, $\Delta d f=1, p=0.58$ ), and $A G F I$ and NNFI decrease slightly while RMSEA rises slightly. Similar to the analysis of $\mathrm{M}_{1}$, adding estimation of the direct relationship 


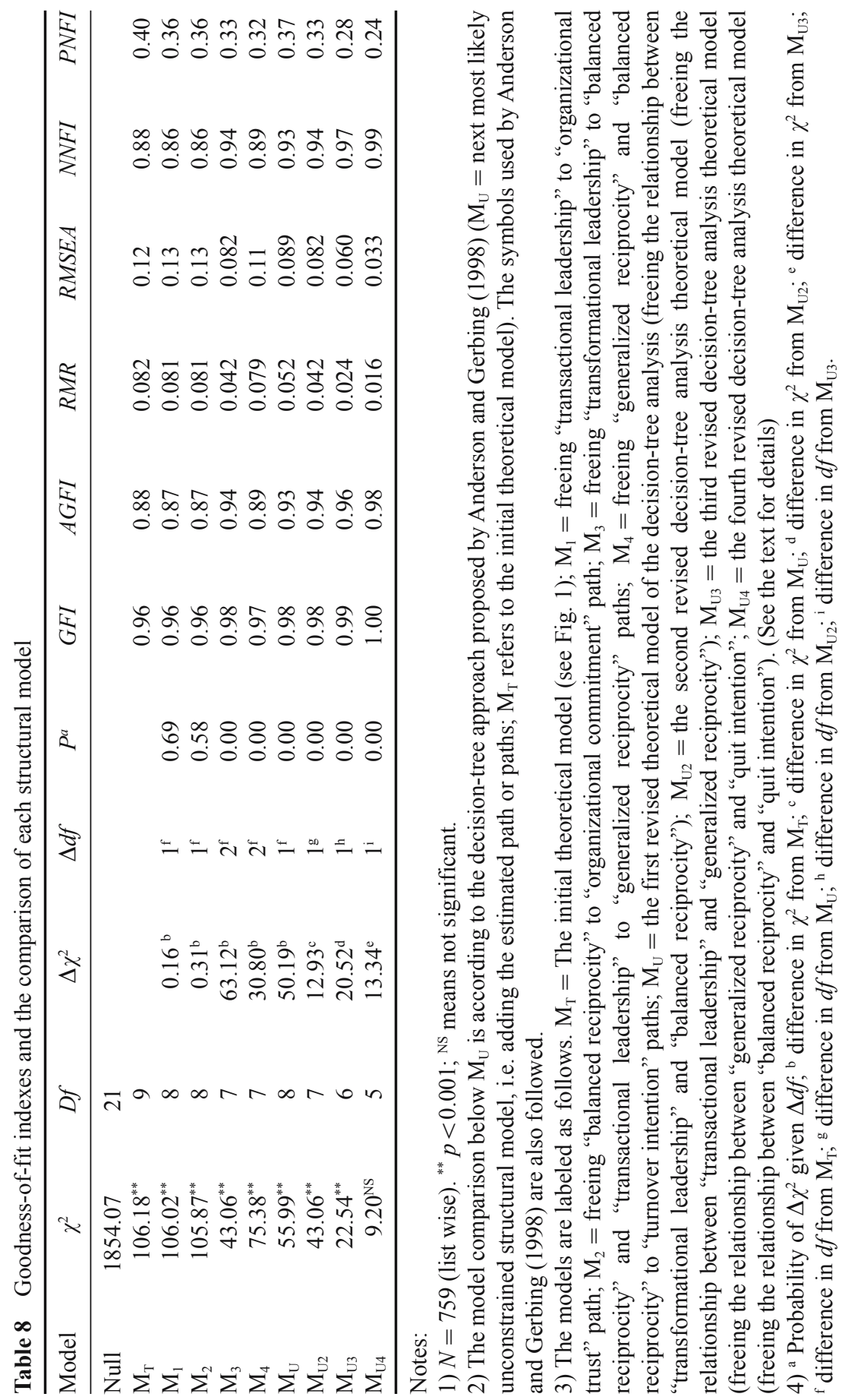


between balanced reciprocity and organizational trust in $\mathrm{M}_{2}$ did not improve the explanatory power even at the cost of parsimony.

\subsubsection{Model $3\left(\mathrm{M}_{3}\right)$}

$\mathrm{M}_{3}$ is based on $\mathrm{M}_{\mathrm{T}}$ by freeing the two paths from transformational leadership to balanced reciprocity and from transactional leadership to generalized reciprocity. Compared with $\mathrm{M}_{\mathrm{T}}$, the $\chi^{2}$ change of $\mathrm{M}_{3}$ is significant $\left(\Delta \chi^{2}=63.12, \Delta d f=2\right.$, $p<0.001)$. GFI, AGFI and NNFI have improved greatly and are all larger than the critical value of $0.90 . R M R$ and $R M S E A$ have decreased greatly, with $R M R$ below the threshold of 0.05 and $R M S E A$ is very close to the critical value of 0.08 . Therefore, adding estimations of the two paths obviously enhances the explanatory power. In $\mathrm{M}_{3}$, the standardized coefficients of the two paths are $0.27(t=5.35$. $p<0.01)$ and $0.19(t=3.25, p<0.01)$ respectively which are both significant at the level of 0.01. Judging from these two coefficients, the remarkable improvement of $\mathrm{M}_{3}$ over $\mathrm{M}_{\mathrm{T}}$ is mainly resulted from adding the estimation path from transformational leadership to balanced reciprocity.

\subsubsection{Model $4\left(\mathrm{M}_{4}\right)$}

$\mathrm{M}_{4}$ is based on $\mathrm{M}_{\mathrm{T}}$ by freeing the two paths from generalized reciprocity and balanced reciprocity to quit intention. Compared with $\mathrm{M}_{\mathrm{T}}$, the $\chi^{2}$ change of $\mathrm{M}_{4}$ is significant $\left(\Delta \chi^{2}=30.80, \Delta d f=2, p<0.001\right)$. GFI, AGFI and NNFI have slightly increased but $A G F I$ and NNFI fall below the threshold of 0.90. RMR and RMSEA decrease slightly but go still beyond the thresholds of 0.05 and 0.08 respectively. Adding the estimation of the two paths enhances the power of $\mathrm{M}_{4}$. But the values of RMR, RMSEA and NNFI reveal poor fit. In $\mathrm{M}_{4}$, the standardized coefficients of the two paths are $0.38(t=5.70, p<0.01)$ and $-0.23(t=-3.12, p<0.01)$ respectively. The relationship between generalized reciprocity and quit intention is inconsistent with the prediction.

4.3.2 The second step analysis: the decision-tree analysis based on the results from the first step analysis $\left(\right.$ see $M_{U}$ to $M_{U 4}$ in the lower part of Table 8)

The Decision-tree approach proposed by Anderson and Gerbing (1988) involves a series of sequential chi-square difference tests (SCDTs). The method estimates the following models, such as the theoretical model $\left(\mathrm{M}_{\mathrm{T}}\right)$, the next most likely constrained structural model $\left(\mathrm{M}_{\mathrm{C}}\right)$ and the next most likely unconstrained structural model $\left(\mathrm{M}_{\mathrm{U}}\right)$, and the saturated model $\left(\mathrm{M}_{\mathrm{S}}\right)$. The saturated model $\left(\mathrm{M}_{\mathrm{S}}\right)$ can be defined as one in which all parameters (i.e. unidirectional paths) relating the constructs to one another are estimated. The degree of freedom of the fully 
saturated model is 0 , and $\chi^{2}$ is also 0 . In the decision-tree approach, the saturated model is as a benchmark model. Nested alternative model can be viewed as the most likely alternative of the $\mathrm{M}_{\mathrm{T}}$ based on the first step analysis. It may be the models either by fixing or freeing path or paths. The below analysis is according to Anderson and Gerbing (1988, p. 420) decision-tree approach.

The first step in the analysis is the comparison of $\mathrm{M}_{\mathrm{T}}-\mathrm{M}_{\mathrm{S}}$. The step assesses if the constraints contained in the theoretical model $\left(\mathrm{M}_{\mathrm{T}}\right)$ are reasonable. If the $\chi^{2}$ difference $\left(\Delta \chi^{2}\right)$ is significant, it indicates that they are reasonable. In the present study, $\mathrm{M}_{\mathrm{S}}$ has a $\chi^{2}$ of zero with zero degrees of freedom due to its fully saturated state. The comparison of $\mathrm{M}_{\mathrm{T}}-\mathrm{M}_{\mathrm{S}}$ is significant $\left(\Delta \chi^{2}=106.18, d f=9, p<0.001\right)$, indicating that the paths constrained to zero in $\mathrm{M}_{\mathrm{T}}$ are reasonable to constrain.

The second analytical step is to compare $M_{C}-M_{T}$, where $M_{C}$ is the next most likely constrained model. Because leadership and reciprocity are of theoretical importance both in theory and in $\mathrm{M}_{\mathrm{T}}(\beta=0.32, t=8.97)$, we constrained the path from transactional leadership to balanced reciprocity. Thus, $\mathrm{M}_{\mathrm{C}}\left(\chi^{2}=166.07\right.$, $d f=10, p<0.001)$ is exactly like $\mathrm{M}_{\mathrm{T}}$ except that the relationship between transactional leadership and balanced reciprocity is constrained to zero. The $\mathrm{M}_{\mathrm{C}}-\mathrm{M}_{\mathrm{T}}$ comparison is significant $\left(\Delta \chi^{2}=59.89, \Delta d f=1, p<0.001\right)$ and the goodness-of-fit indexes obviously get worse, indicating that constraining the transactional leadership and generalized reciprocity relationship significantly degrades the fit of $\mathrm{M}_{\mathrm{C}}$.

The above comparison leads us to the third step of the analysis, the comparison of $\mathrm{M}_{\mathrm{T}}-\mathrm{M}_{\mathrm{U}}$. Model $\mathrm{M}_{\mathrm{U}}\left(\chi^{2}=55.99, d f=8, p<0.001\right)$ comes from freeing the relationship between transformational leadership and balanced reciprocity, which has been found to be important in $\mathrm{M}_{3}$. The $\mathrm{M}_{\mathrm{T}}-\mathrm{M}_{\mathrm{U}}$ comparison results in a significant $\chi^{2}$ difference $\left(\Delta \chi^{2}=50.19, \Delta d f=1, p<0.001\right)$, indicating that allowing this relationship to be freely estimated significantly improves the fit of $\mathrm{M}_{\mathrm{U}}$.

The previous analyses complete the three $\left(\mathrm{M}_{T}-\mathrm{M}_{\mathrm{S}}, \mathrm{M}_{\mathrm{C}}-\mathrm{M}_{\mathrm{T}}\right.$ and $\left.\mathrm{M}_{\mathrm{T}}-\mathrm{M}_{\mathrm{U}}\right)$ comparisons that the logic of the decision-tree approach suggests as being necessary to rigorously examine the theoretical model and its nested alternatives. At this point of analysis, compared to $\mathrm{M}_{\mathrm{T}}, \mathrm{M}_{\mathrm{U}}$ appears to be the preferred alternative model. However, the decision-tree approach provides an additional logic to explore the possibility of freeing more constraints in $\mathrm{M}_{\mathrm{U}}$. Anderson and Gerbing (1988) cautioned that the further we go, the more exploratory the nature of our decision-tree analysis is. Theoretically, we can repeat the above comparison steps and free more and more paths until the most parsimonious model is not significantly different from $\mathrm{M}_{\mathrm{S}}$.

The first part of this additional analysis started with a comparison of $\mathrm{M}_{U}-\mathrm{M}_{\mathrm{S}}$ (the comparison logic is the same as above, and $\mathrm{M}_{\mathrm{U}}$ is now regarded as the new $\left.M_{T}\right)$. The comparison goes till the comparison of $M_{U 4}-M_{S}$, where $M_{U 4}\left(\chi^{2}=9.20\right.$, 
$d f=5$, NS) is not significantly different from $\mathrm{M}_{\mathrm{S}}$, indicating that no more constraints in $\mathrm{M}_{\mathrm{U} 4}$ can be reasonably removed and still improve the fit of the model. Thus, $\mathrm{M}_{\mathrm{U} 4}$ is accepted as the "final" model in this analysis.

Taking account of model $\mathrm{M}_{4}$ in the previous analysis, additionally freeing the relationships from generalized reciprocity and balanced reciprocity to quit intention improves the fit but not significantly due to poor fit values. The relationship between generalized reciprocity and quit intention is inconsistent with the prediction. Therefore, given the caveat of Anderson and Gerbing (1988), $\mathrm{M}_{\mathrm{U} 2}$ should be regarded as the most defensible model (see Fig. 2), with $\mathrm{M}_{\mathrm{U} 3}$ and $\mathrm{M}_{\mathrm{U} 4}$ being considered as theoretically interesting possibilities which warrant further studies.

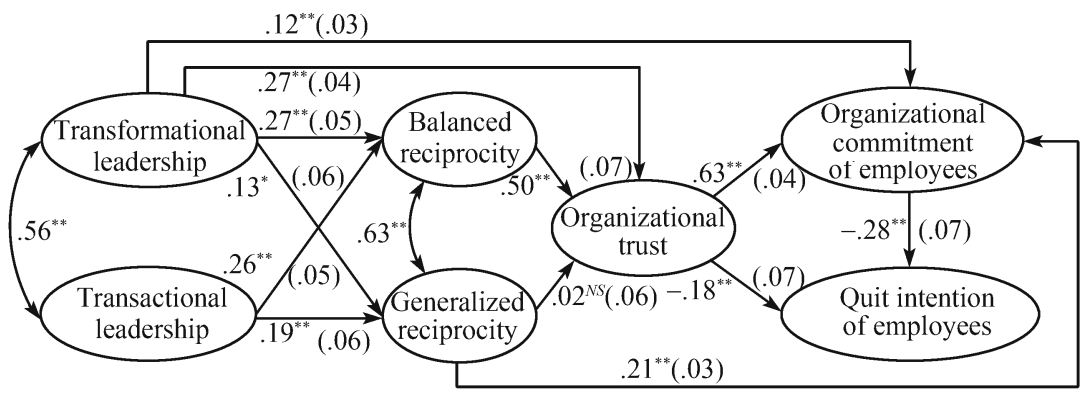

Fig. 2 Structural model of the mediating effects of reciprocity and trust on the relationship between leadership and job-related attitudes of employees $\left(\mathrm{M}_{\mathrm{U} 2}\right)$

Notes: 1) The numbers on the arrow lines are non-standardization coefficients, and those on the arc lines are correlation coefficients; the standard errors are showed in parentheses.

2) ${ }^{* *} p<0.01 ;{ }^{*} p<0.05$.

\subsection{Results of hypotheses test}

From the above analyses, we accept the model $\mathrm{M}_{\mathrm{U} 2}$, which is based on $\mathrm{M}_{\mathrm{T}}$ by freeing the relationships between transformational leadership and balanced reciprocity, and between transactional leadership and generalized reciprocity. As shown in Table 8, the model $\mathrm{M}_{\mathrm{U} 2}$ fits very well to the data with GFI, AGFI and NNFI over the threshold of 0.90 , and RMR below the threshold of 0.05 , and only RMSEA slightly above the threshold of 0.08 . As presented in Fig. 2, the impact of transformational leadership on generalized reciprocity is significant $(\beta=0.13, t=2.41, p<0.05)$; transactional leadership also has a significant impact on balanced reciprocity $(\beta=0.26, t=4.94, p<0.01)$; transformational leadership has significant impacts on organizational trust $(\beta=0.27, t=7.04$, $p<0.01)$ and on organizational commitment $(\beta=0.12, t=3.84, p<0.01)$. Therefore, hypothesis $1,2,3$ and 8 are supported. 
As shown in Table 7, generalized reciprocity positively and significantly relates to organizational trust $(r=0.461, p<0.01)$ while balanced reciprocity is positively and significantly related to organizational trust $(r=0.627, p<$ 0.01). As also shown in Fig. 2, balanced reciprocity has a significant impact on organizational trust. However, generalized reciprocity has an insignificant effect on organizational trust $(\beta=0.02, t=0.51)$. Therefore, hypothesis 5 is supported, where balanced reciprocity is positively related to organizational trust. Hypothesis 4 is not supported, where generalized reciprocity almost has no impact on the organizational trust and is significantly weaker than the impact of balanced reciprocity when the co variation between generalized and balanced reciprocity is taken into account.

As demonstrated in Table 7, transformational leadership, generalized reciprocity, and organizational trust are significantly and positively correlated to one another, and so do transactional leadership, balanced reciprocity and organizational trust. According to the suggestion of Baron and Kenny (1986) and by comparing model $\mathrm{M}_{\mathrm{T}}$ with $\mathrm{M}_{1}$, we can see that the direct relationship between transactional leadership and organizational trust is not significant while transformational leadership influences organizational trust directly and significantly. According to the above analyses, after considering the co-variation between we found that generalized reciprocity and balanced reciprocity, generalized reciprocity almost does not affect organizational trust. Thus, balanced reciprocity plays a full mediating role in the relationship between transformational leadership and organizational trust. Therefore, hypothesis 6 and 7 are supported: generalized reciprocity and balanced reciprocity fully mediate the relationship between transactional leadership and organizational trust while partially mediate the relationship between transformational leadership and organizational trust.

As shown in Table 7, generalized reciprocity is significantly and positively correlated with organizational commitment $(r=0.533, p<0.01)$. Organizational trust has a significantly positive correlation with organization commitment $(r=0.792, p<0.01)$. Organizational trust relates both significantly and negatively to quit intention $(r=-0.286, p<0.01)$. Organizational commitment also has a significantly negative correlation with quit intention $(r=-0.402, p<0.01)$. As presented in Fig. 2, generalized reciprocity affects organizational commitment significantly $(\beta=0.21, t=6.50, p<0.01)$. Organizational trust also affects organizational commitment significantly $(\beta=0.63, \quad t=18.17, \quad p<0.01)$. Organizational trust affects quit intention significantly $(\beta=-0.18, t=-2.64$, $p<0.01$ ), and organizational commitment affects quit intention significantly $(\beta=-0.28, t=-4.09, p<0.01)$. Therefore, hypothesis $9-12$ are supported.

Taken together, almost all hypotheses based on the theoretical model are supported except hypothesis 4. What differ from the theoretical model and proposed hypotheses are as follows. First, generalized reciprocity has almost 
no impact on organizational trust and is significantly weaker than the impact of balanced reciprocity when the co-variation between generalized and balanced reciprocity are taken into account. Second, transformational leadership directly affects organizational trust and indirectly exerts influences on trust through both generalized reciprocity and balanced reciprocity.

\section{Conclusion and discussion}

\subsection{Conclusion and theoretical contributions}

The purpose of our study is to examine the mediating effects of reciprocity and organizational trust on the relationship between leadership and job-related attitudes of employees on the basis of social exchange theory. The findings from this study improve our understanding of the mechanism by which leaders affect job-related attitudes of their subordinates.

First, the study confirms the mediating roles of generalized and balanced reciprocity between transformational leadership and organizational trust, and the mediating roles of generalized reciprocity, balanced reciprocity and organizational trust between transformational leadership and job-related attitudes of employees. Transformational leaders can induce the employees to generate organizational trust through producing the exchange norm of generalized and balanced reciprocity, and result in promotion of employees' commitment and decrease of their quit intention. The findings also show that generalized reciprocity and balanced reciprocity both play a mediating role in the relationship between transactional leadership and organizational trust, thus enhancing the employees' commitment and reducing their quit intention. Some researchers used to regard justice and trust as mediating variables on the association between transformational leadership and organizational citizenship behavior of employees (Pillai et al., 1999). It is the first time in the literature to use the norm of reciprocity as a mediating variable. Reciprocity is the universal principle in human activities and Sahlins (1972) had already proposed that the norm of reciprocity could be operated in three dimensions, i.e. equivalence, immediacy and interest. Nevertheless, research on the direct measurement of reciprocity is still at its starting stage (Wu et al., 2006). Wu et al. (2006) developed and tested the reciprocity scale in the context of China. Not only does our study deepen the understanding about how leadership affects employees' attitudes, it also validates the work of Wu et al. (2006) about reciprocity to a certain degree.

Second, generalized reciprocity and balanced reciprocity play a full mediating role in the relationship between transactional leadership and organizational trust, while a partially mediating role in the relationship between transformational 
leadership and organizational trust. We can see that reciprocity plays a very important role in the relationship between leaders and employees, especially in Chinese culture which emphasizes the norm of "returning the favor (i.e. if one receives a plum, one must return a peach)". Transactional leadership focuses on the clear relationship between employees' reward and performance and enables employees to have a sense of organizational trust by signaling to them the employer's emphases on equivalence and immediacy of return. Transformational leadership stresses leaders' charisma and inspirational motivation, thus affects the employees' attitudes through articulating the vision, conveying the mission, showing determination and expressing high expectation of performance. These characteristics make employees convinced that the organization emphasizes the open-endedness, broadness and uncertainty of reimbursement that arouse the employees' self-motivation to reimburse organization in the future, thereby resulting in employees' organizational trust. In addition to this indirect effect, transformational leadership can directly affect the organizational trust of employees.

Third, after the co-variation between generalized and balanced reciprocity is considered, generalized reciprocity almost has no impact on the organizational trust of employees, while balanced reciprocity still affects organizational trust significantly. In $\mathrm{M}_{2}$, the relationship between balanced reciprocity and organizational commitment of employees is not significant $(\beta=0.03, t=0.60)$, and $\mathrm{M}_{2}$ does not significantly improve $\mathrm{M}_{\mathrm{T}}\left(\Delta \chi^{2}=0.31, \Delta d f=1, p=0.58\right)$. Therefore, the possible interpretation might be that generalized reciprocity directly affects organizational commitment, thus reducing employees' quit intention; while balanced reciprocity indirectly influences organizational commitment through the organizational trust of employees, thus reducing employees' quit intention.

\subsection{Practical implications}

Middle managers are the backbones of enterprises and the most valuable resources. Their organizational commitment and willingness to stay represent their identification with, involvement in and loyalty to the enterprises. Such commitment and loyalty are one of the most important sources of the enterprises' competitiveness and sustainable competitive advantage. We study the process of how leadership affects managers' attitudes (organizational commitment and willingness to stay). Some practical implications can be given to the enterprises and leaders in China.

First, not only can transformational leadership inspire the employees with organizational trust through generalized and balanced reciprocity, it also 
directly bestir the employees' organizational trust, and thus increase employees commitment and willingness to stay. Such a finding reveals that managers, especially at the top level, should become transformational leaders. How to discipline themselves to be transformational? According to numerous studies by Bass and Avolio (1993), Waldman et al. (2001) and others, the main contents of disciplining at least include: building a shared vision; showing competence and confidence; showing determination and communicating high performance expectations; going beyond self-interest for the good of team and organization; creating a pleasant climate, etc.

Second, reciprocity and trust play mediating roles in the relationship between leadership and the work attitudes. This finding tells that enterprise leaders should construct an organizational culture full of trust and reciprocity. Trust is based on reciprocity, and it is hard to create a sense of trust without reciprocity of exchange (McCabe et al., 2003). We can foster a culture full of trust through two ways. One is to foster the trust of the organization to its stakeholders by showing fairness and honesty in the process of competing and/or cooperating with customers, suppliers, rivals, employees, government, communities and other stakeholders. The overall sense of trust of the organization could make its employees feel that the company is honest and trustworthy, and believe that the behaviors and intentions of the company are good. The other way is to nurture the specific trust of organization in employees during the process of numerous deals of company with employees.

Third, leaders of enterprises should build the culture and systems signaling generalized and balanced reciprocity with employees. Both open-ended and close-ended investments of an organization in its employees are conducive to nurturing organizational commitment of employees and reducing their quit intention. In a survey by Ma (2004) with 472 valid questionnaires (almost all of the respondents are managers and technicians), nearly half of the respondents (48.9\%) responded that "providing training opportunities for their staff" was the most valuable help from enterprises in the employees' eyes, while "offering an opportunity for promotion" was answered by only $17.4 \%$. "Providing training opportunities for its staff" is indicative of both generalized and balanced reciprocity of an enterprise to its employees.

As some old Chinese sayings go, "the benevolent ones love people", "those who gain the support from the people get the world". Since the 1980s, human resources have been gradually seen as the most valuable resources of organizations, and the competition in the $21^{\text {st }}$ century has been being the competition of talents. One of the major avenues to enhance and maintain the company competitiveness relies on its leaders' constant disciplining of their leadership and competency, and culture building characterized by reciprocity and 
trust. It is a key way to foster the employees' especially the talents' organizational commitment and retention.

\subsection{Limitations and future direction of research}

Due to the operational difficulties in data collection, the main limitations of this study are the potential problems of cross-sectional data and common method variance. Although the Harman single factor test and discriminant validity test demonstrate that the measurement properties of this study are pretty well, yet future research can still be improved in data collection. For example, let the subordinates and their supervisors fill in different questionnaires, and collect data of predictive and criterion variables sequentially with a certain interval (Podsakoff, et al., 2003).

In the exploratory study, we found the "management by exception" factor of transactional leadership was entirely involved in the concept of transformational leadership. In this study, the "contingent reward" factor was only used to measure transformational leadership. To the best of our knowledge, existing studies of domestic scholars have concerned more about transformational than transactional leadership, e.g. Li and Shi (2003) and Meng et al. (2004). Therefore, further studies are needed to test the reliability and validity of transactional leadership in Chinese context.

Acknowledgements We are grateful to the comments of Professor Anne S. Tsui and reviewers of Frontiers of Business Research in China. This research is sponsored by the National Science Foundation of China (70572049) and a Research Foundation (2006031751) in Renmin University of China.

\section{References}

Allen N, Meyer J P (1990). The measurement and antecedents of affective, continuance and normative commitment to the organization. Journal of Occupational Psychology, 62(1): $1-18$

Anderson J C, Gerbing D W (1988). Structural equation modeling in practice: A review and recommended two-step approach. Psychological Bulletin, 103(3): 411-423

Avolio B J, Zhu W, Koh W, Bhatia P (2004). Transformational leadership and organizational commitment: Mediating role of psychological empowerment and moderating role of structural distance. Journal of Organizational Behavior, 25(8): 951-968

Baron R M, Kenny D A (1986). The moderator-mediator variable distinction in social psychological research: Conceptual, strategic, and statistical considerations. Journal of Personality and Social Psychology, 51(6): 1,173-1,182

Bass B M (1985). Leadership and Performance beyond Expectations. New York: Free Press

Bass B M (1999a). Two decades of research and development in transformational leadership. European Journal of Work and Organizational Psychology, 8(1): 9-32 
Bass B M (1999b). On the taming of charisma: A reply to Janice Beyer. Leadership Quarterly, 10(4): 541-553

Bass B M, Avolio B J (1990). The implications of transactional and transformational leadership for individual, team, and organizational development. In: Woodman R W, Pasmore W A, eds. Research in Organizational Change and Development. Greenwich, CT: JA1 Press

Bass B M, Avolio B J (1993). Transformational leadership: A response to critiques. In: Chemers M M, Ayman R, eds. Leadership Theory and Research: Perspective and Directions. San Diego: Academic Press

Blau P (1988). The Exchange and Power in Social Life. Beijing: Huaxia Publishing House (in Chinese)

Bluedorn A C (1982). A unified model of turnover from organization. Human Relations, 35(2): $135-153$

Brockner J, Siegel P, Daly J, Tyler T, Martin C (1997). When trust matters: The moderating effect of outcome favorability. Administrative Science Quarterly, 42(3): 558-583

Bryman A (1992). Charisma and Leadership in Organizations. Newbury Park, CA: Sage

Burns J M (1978). Leadership. New York: Harper \& Row

Butler J K (1991). Toward understanding and measuring conditions of trust: Evolution of conditions of trust inventory. Journal of Management, 17(3): 643-663

Bycio P, Hackett R D, Allen J S (1995). Further assessments of Bass's (1985) conceptualization of transactional and transformational leadership. Journal of Applied Psychology, 80(4): $468-478$

Chen L Y (2002). An examination of the relationship between leadership behavior and organizational commitment at steel companies. Journal of Applied Management and Entrepreneurship, 7(2): 122-142

Chen Y X, Jia L D, Li C P, Song L J, Zhang J J (2006). Transformational leadership, psychological empowerment and job-related attitudes of employees: An empirical study under Chinese context. Management World, (1): 97-105, 144 (in Chinese)

Chen Z X, Francesco A M (2003). The relationship between the three components of commitment and employee performance in China. Journal of Vocational Behavior, 62(3): $490-510$

Cotton J L, Tuttle J M (1986). Employee turnover: A meta-analysis and review with implications for research. Academy of Management Review, 11(1): 55-70

DeCoutis T A, Summers T P (1987). A path analysis of a model of the antecedents and consequences of organizational commitment. Human Relations, 40(7): 445-470

Dirks K T, Ferrin D L (2002). Trust in leadership: Meta-analytic findings and implications for research and practice. Journal of Applied Psychology, 87(4): 611-628

Dvir T, Eden D, Avolio B J, Shamir B (2002). Impact of transformational leadership on follower development and performance: A field experiment. Academy of Management Journal, 45(4): 735-744

Ferris K R, Aranya N (1983). A comparison of two organizational commitment scales. Personnel Psychology, 36(1): 87-98

Fishbein M (1967). Attitude and the prediction of behavior. In: Fishbein M, ed. Readings in Attitude Theory and Measurement. New York: Wiley

Gouldner A W (1960). The norm of reciprocity: A preliminary statement. American Sociological Review, 25(2): 161-178

Hair J F, Anderson R E, Tatham R L, Black W C (1998). Multivariate Data Analysis (5th ed). NJ: Prentice-Hall 
Howell J M, Avolio B J (1993). Transformational leadership, transactional leadership, locus of control, and support for innovation: Key predictors of consolidated-business-unit performance. Journal of Applied Psychology, 78(6): 891-902

Jöreskog K G, Sörbom D (1993). LISREL 8: User's Reference Guide. Chicago, IL: Scientific Software

Kellerman B (1984). Leadership: Multidisciplinary Perspectives. Englewood Cliffs, NJ: Prentice-Hall

Kelloway K (1998). LISREL for Structural Equation Modeling: A Researcher's Guide. Thousand Oaks: Sage

Konovsky M, Pugh S D (1994). Citizenship behavior and social exchange. Academy of Management Journal, 37(3): 656-669

Kuhnert K W, Lewis P (1987). Transactional and transformational leadership: A constructive/ developmental analysis. Academy of Management Review, 12(4): 648-657

Li Chaoping, Shi Kan (2003). Transformational leadership and its relationship with leadership effectiveness. Psychological Science (in Chinese), 26(1): 115-117

Lum L, Kervin J, Clark K, Reid F, Sirola W (1998). Explaining nursing turnover intent: Job satisfaction, pay satisfaction, or organizational commitment? Journal of Organizational Behavior, 19(3): 305-320

Ma Shibin (2004). Do employees need enterprises to help their career development? Talents, (12): 73-75 (in Chinese)

Mayer R C, Davis J H, Schoorman F D (1995). An integrative model of organizational trust. Academy of Management Review, 20(3): 709-734

McAllister D J (1995). Affect- and cognition-based trust as foundations for interpersonal cooperation in organizations. Academy of Management Journal, 38(1): 24-59

McCabe K A, Rigdon M L, Smith V L (2003). Positive reciprocity and intentions in trust games. Journal of Economic Behavior and Organization, 52(2): 267-275

McNeilly K M, Lawson M B (1999). Navigating through rough waters: The importance of trust in managing sales representatives in times of change. Industrial Marketing Management, 28(1): 37-49

Meindl J R (1990). On leadership: An alternative to the conventional wisdom. In: Staw B M, Cummings L L, eds. Research in organizational behavior. Greenwich, CT: JAI Press

Meng Hui (2004). An empirical study of transformational leadership. Applied Psychology, 10(2): 18-22 (in Chinese)

Meyer J P, Allen N J (1984). Testing the "side-bet theory" of organizational commitment: Some methodological considerations. Journal of Applied Psychology, 69(3): 372-378

Meyer J P, Allen N J (1997). Commitment in the Workplace: Theory, Research and Application. Thousand Oaks, CA: Sage

Michaels C, Spector P (1982). Cause of employee turnover: A test of the Mobley, Griffeth, Hand and Meglino model. Journal of Applied Psychology, 67(1): 53-59

Mobley W H, Horner S O, Hollingsworth A T (1978). An evaluation of precursors of hospital employee turnover. Journal of Applied Psychology, 63(4): 408-414

Mueller C W, Price J L (1990). Economic, psychological and sociological determinants of voluntary turnover. Journal of Behavior Economics, 19(3): 321-335

Newman J E (1974). Predicting absenteeism and turnover: A field comparison of Fishbein's model and traditional job attitude measures. Journal of Applied Psychology, 59(5): $610-615$

Niehoff B P, Moorman R H (1993). Justice as a mediator of the relationship between methods of monitoring and organizational citizenship behavior. Academy of Management Journal, 36(3): $527-556$ 
O'Reilly C A, Caldwell D F (1980). Job choice: The impact of intrinsic and extrinsic factors on subsequent satisfaction and commitment. Journal of Applied Psychology, 59(5): 610-615

Pillai R, Schriesheim C A, Williams E S (1999). Fairness perceptions and trust as mediators for transformational and transactional leadership: A two-sample study. Journal of Management, 25(6): 897-933

Podsakoff P M, MacKenie S B, Lee J Y, Podsakoff N P (2003). Common method biases in behavioral research: A critical review of the literature and recommended remedies. Journal of Applied Psychology, 88 (5): 879-903

Podsakoff P M, Organ D W (1986). Self-reports in organizational research: Problems and prospects. Journal of Management, 12(4): 531-544

Rhoades L, Eisenberger R (2002). Perceived organizational support: A review of the literature. Journal of Applied Psychology, 87(4): 698-710

Robbins S P, Coulter M (2002). Management (7th edition). Beijing: Tsinghua University Press (original publisher Pearson Education, Inc.)

Roberts J A, Coulson K R, Chonko L B (1999). Salesperson perceptions of equity and justice and their impact on organizational commitment and intent to turnover. Journal of Marketing Theory and Practice, 7(1): 1-16

Robinson S L (1996). Trust and breach of the psychological contract. Administrative Science Quarterly, 41(4): 574-599

Rockwell R C (1975). Assessment of multi-colinearity: The Haitovsky test of the determinant. Sociological Methods and Research, 3(2): 308-320

Sahlins M (1972). Stone Age Economics. New York: Aldine De Gruyter

Settoon R P, Bennett N, Liden R C (1996). Social exchange in organizations: Perceived organizational support, leader-member exchange, and employee reciprocity. Journal of Applied Psychology, 81(3): 219-227

Shamir B, House R J, Arthur M B (1993). The motivational effects of charismatic leadership: A self-concept based theory. Organizational Science, 4(2): 577-594

Shin S J, Zhou J (2003). Transformational leadership, conservation, and creativity: Evidence from Korea. Academy of Management Journal, 46(6): 703-714

Shore L M, Shore T H (1995). Perceived organizational support and organizational justice. In Cropanzano R S, Kacmar M (Eds). Organizational Politics, Justice, and Support. 149-164, Westport, CT: Quorum

Shore L M, Martin H (1989). Job satisfaction and organizational commitment in relation to work performance and turnover intentions. Human Relations, 42(7): 625-638

Siegel P, Brockner J, Tyler T (1995). Revisiting the interactive relationship between procedural and distributive justice: The role of trust. Paper presented at the Academy of Management Meeting, Vancouver

Sparrowe R T, Liden R C (1997). Process and structure in leader-member exchange. Academy of Management Review, 22(2): 522-552

Spector P E (1994). Using self-report questionnaires in OB research: A comment on the use of a controversial method. Journal of Organizational Behavior, 15(5): 385-392

Stumpf S A, Hartman K (1984). Individual exploration to organizational commitment or withdrawal. Academy of Management Journal, 27(3): 308-329

Tetrick L E, Shore L M, Tsui A S, Wang D X, Glenn D, Chen N, Liu H, Wang X C, Yan H F (2004). Development of a measure of generalized, balanced, and negative reciprocity in employment relationships. Paper presented at IACMR conference, Beijing

Tyler T R (1986). The psychology of leadership evaluation. In: Bierhoff H W, Cohen R L, Greenberg J, eds. Justice in Social Relations. NY: Plenum 
Tyler T R (1989). The psychology of procedural justice: A test of the group values model. Journal of Personality and Social Psychology. 57(5): 830-838

Tyler T R, Caine A (1981). The influence of outcomes and procedures on satisfaction with formal leaders. Journal of Personality and Social Psychology, 41(5): 642-655

Waldman D A, Ramirez G G, House R J, Puranam P (2001). Does leadership matter? CEO leadership attributes and profitability under conditions of perceived environmental uncertainty. Academy of Management Journal, 44(1): 134-143

Wang H, Law K S, Chen G (2002). A structural equation model of the effects of multidimensional leader-member exchange on task and contextual performance. Presented at the 17th Annual Conference on Society of Industrial and Organizational Psychology (SIOP), Toronto

Wang H, Law K S, Hackett R D, Wang D, Chen Z (2005). Leader-member exchange as a mediator of the relationship between transformational leadership and followers' performance and organizational citizenship behavior. Academy of Management Journal, 48(3): 420-432

Wayne S J, Shore L M, Liden R C (1997). Perceived organizational support and leader-member exchange: A social exchange perspective. Academy of Management Journal, 40(1): 82-111

Whitener E M, Brodt S E, Korsgaard M A, Werner J M (1998). Managers as initiators of trust: An exchange relationship framework for understanding managerial trustworthy behavior. Academy of Management Review, 23(3): 513-530

Williams L J, Hazer J T (1986). Antecedents and consequences of satisfaction and commitment in turnover models: A reanalysis using latent variable structural equation methods. Journal of Applied Psychology, 71(2): 219-231

Wu J B, Hom P W, Tetrick L E, Shore L M, Jia L D, Li C P, Song L J (2006). The norm of reciprocity: Scale development and validation in the Chinese context. Management and Organization Review, 2(3): 377-402

Yousef D A (2000). Organizational commitment: A mediator of the relationships of leadership behavior with job satisfaction and performance in a non-western country. Journal of Managerial Psychology, 15(1): 6-28

Yukl G A (1989). Managerial leadership: A review of theory and research. Journal of Management, 15(2): 251-289 